\title{
Operacja ,Oluja” i spory wokół jej interpretacji
}

\author{
$Z$ chorwackiej perspektywy „Oluja” \\ to pojęcie tożsame ze zwycięstwem, \\ symbol udanego zakończenia wieloletniej wojny. \\ $Z$ serbskiej perspektywy, \\ $i$ to nie tylko $w$ Chorwacji, \\ „Oluja” to catkowicie inny symbol.
}

Davor Marijan $^{1}$

Wojskową operację „Oluja” („Burza”) przeprowadzono w sierpniu 1995 r. na obszarze dzisiejszej Republiki Chorwacji. Zorganizowana została przez siły zbrojne młodego państwa chorwackiego. Miała na celu przejęcie kontroli administracyjnej (i faktycznej), przy użyciu wojska, nad obszarem zamieszkanym przez Serbów, funkcjonującym od $1991 \mathrm{r}$. pod nazwą Republika Serbska Krajina (RSK). Akcja skutkowała opuszczeniem tego obszaru przez ludność serbska, która udała się na terytorium Bośni i Hercegowiny (BiH) lub Federacyjnej Republiki Jugosławii (SRJ) ${ }^{2}$. Zakończona sukcesem operacja wojskowa pozwoliła na realizację planu

${ }^{1}$ D. Marijan, Oluja, Zagreb 2007, s. 33.

${ }^{2}$ Głównie na tereny wchodzącej w jej skład Republiki Serbii. 
przejęcia kontroli nad terytorium RSK i objęcia go jednolitym systemem politycznym, administracyjnym i prawnym, budowanym po ogłoszeniu przez Chorwację samodzielności państwowej w czerwcu 1991 r. $^{3}$

Operacja „Oluja”, a zwłaszcza jej polityczny i społeczny odbiór, stanowi jeden z zasadniczych punktów niezgody, jeśli chodzi o proces żmudnego budowania relacji serbsko-chorwackich po roku 1995. Problem polega na odmiennym postrzeganiu tego wydarzenia, które znakomita część opinii chorwackiej interpretuje jako zwycięską operację wojskowa, zgodna z zasadami sztuki wojennej, a przy okazji nie łamiąca międzynarodowych regulacji dotyczących ochrony ludności cywilnej. Umożliwiła ona odzyskanie, wyzwolenie lub też uwolnienie spod okupacji serbskiej. Jeszcze bardziej sporne jest ujmowanie opuszczenia przez około 250 tys. serbskich cywili obszaru RSK. Chorwaci mówią o ucieczce lub ewakuacji ludności, chociaż najczęstszym słowem, pojawiającym się w ich źródłach, jest odejście/wyjazd (oryg. odlazak).

Żadne z tych ujęć nie jest z kolei podzielane przez Serbów, z wyjątkiem pojęcia ewakuacji. Jednak zazwyczaj są one używane w kontekście lęku przed ofensywą wojsk chorwackich, która została podjęta pod przymusem, nie zaś zorganizowana pod wpływem wolnej woli (o czym będzie mowa poniżej). Operacja „Oluja” jest postrzegana wprawdzie jako świetnie zorganizowana operacja wojskowa, jednak docelowo miała to być czystka etniczna polegająca na wypędzeniu Serbów z Chorwacji lub ich likwidacji. Chorwaccy Serbowie nie uważali się

${ }^{3}$ Wprawdzie przepisy na obszarze Chorwacji zaczęły być wprowadzane od momentu uchwalenia jej konstytucji w 1990 r., jednak dopiero separacja od Socjalistycznej Federacyjnej Republiki Jugosławii wprowadziła faktyczną wyższość tych przepisów, znosząc te jugosłowiańskie.

${ }^{4}$ Ibidem, s. 36; A. Nazor, Riječ urednika, [w:] ibidem, s. 7.

${ }^{5}$ A. Nazor, op. cit., s. 11. 
za okupantów zamieszkiwanych przez siebie obszarów, więc tym samym za kogoś, kto rościł sobie pretensje do odebrania cudzego obszaru. Uważali się za autochtonów, którzy przybyli na te ziemie kilkaset lat temu (głównie w końcu XVII w.). W momencie rozpadu państwa jugosłowiańskiego, gdy jednostronne deklaracje niepodległościowe (Słowenii i Chorwacji) prowadziły do uzyskania samodzielności państwowej, akceptowanej na arenie międzynarodowej, Serbowie również chcieli z tego prawa skorzystać ${ }^{6}$.

Należy podkreślić, że stanowisko chorwackie nie jest do końca jednolite w postrzeganiu tej operacji. Wprawdzie nie ma wątpliwości co do tego, że była ona niezbędna, to jednak niewielka część chorwackich badaczy tego tematu (wśród nich sa i chorwaccy Serbowie, tacy jak Svetozar Livada ${ }^{7}$ czy Živko Juzbašićc $^{8}$ ) uwzględnia kwestię sytuacji ludności serbskiej.

Podobnie wśród serbskich opinii można znaleźć rozbieżności, dotyczące genezy operacji „Oluja”. Nie jest wprawdzie

${ }^{6}$ Szerzej ten temat zostanie poruszony w rozważaniach w dalszej części tekstu, zob.: C. Нишић, Хрватска Олуја и српске сеобе, Београд 2006 , s. 127; J. Skowronek, M. Tanty, T. Wasilewski, Stowianie południowi i zachodni VI-XX wiek, Warszawa 2005, s. 152; В. Гречић, Главна обележја сеоба српског народа, [w:] Сеобе Срба некад и сад, ур. В. Гречић, Београд 1990, s. 27; Ž. Juzbašić, Srpsko pitanje i hrvatska politika. Svjedočanstva i dokumenti 1990-2000, Zagreb 2009, s. 39.

${ }^{7}$ Svetozar Livada - urodzony w Slunju (na obszarze dzisiejszej Republiki Chorwacji) - filozof, socjolog i polityk, który podczas wojny w Chorwacji był konsultantem ds. pomocy humanitarnej przy dowództwie sił pokojowych Narodów Zjednoczonych na obszarze Sektora Północ (Banovina, Kordun).

${ }^{8}$ Živko Juzbašić - urodzony w Jošavicy, koło Petrinja (na obszarze dzisiejszej Republiki Chorwacji) - polityk i członek komitetu negocjacyjnego ds. zawieszenia broni i wymiany jeńców, członek delegacji haskiej chorwackiej grupy eksperckiej ds. ochrony praw człowieka i mniejszości, w latach 1991-1992 był jedynym politykiem serbskiej narodowości w chorwackim rządzie; bezpartyjny. 
dyskutowany sam fakt jej przeprowadzenia oraz konsekwencji dla chorwackich Serbów, natomiast rozbieżne są opinie na temat roli i współodpowiedzialności Belgradu, o czym również będzie mowa poniżej.

Opracowanie to jest próbą odpowiedzi na pytanie, czy można wypracować wspólne stanowisko oraz wygasić kontrowersje serbsko-chorwackie wokół operacji „Oluja”. Na początku zostaną omówione podstawowe problemy historiografii tematu. W kolejnej części będzie przedstawione ujęcie operacji „Oluja”, głównie w badaniach chorwackich oraz serbskich, wsparte innymi źródłami ${ }^{9}$ Koncentruję się głównie

${ }^{9}$ Najważniejsze dokumenty, które wniosły najwięcej informacji faktograficznych, to raport Helsińskiej Fundacji Praw Człowieka, dotyczący operacji „Oluja” i zbrodni popełnionych na ludności serbskiej: Croatia. Impunity for Abuses Committed during "Operation Storm" and the Denial of the Right of Refugees to Return to Krajina, Human Rights Watch/Helsinki, August 1996, vol. 8, no. 13, http://www.hrw.org/reports/pdfs/c/croatia/ croatia968.pdf (dostęp 9 VI 2014); a także transkrypty rozpraw procesów w Hadze przeciwko Ante Gotovinie, Mladenowi Markačowi i Slobodanowi Miloševiciowi. Bardzo ważne były również informacje uzyskane z publikowanych wspomnień Carli Del Ponte (główna prokurator Międzynarodowego Trybunału Karnego dla byłej Jugosławii - od 1999 r. do 2007 r.), К. Дел Понте, Обвинителката во лов. Соочувања со најлошите злосторниии на човештвото и културата на неказивност, Скопје 2008; oraz wywiady i notatki polskiego dziennikarza Ryszarda Bilskiego, przebywajacego podczas wojen na obszarze byłej Jugosławii, R. Bilski, Kocioł batkański, Warszawa 2000. Wśród podstawowych opracowań można wymienić teksty: M. Bjelajac, O. Žunec, Rat u Hrvatskoj, 1991-1995, [w:] Suočavanje s jugoslavenskim kontroverzama. Inicjativa naučnika, prir. Ch. Ingrao, T.A. Emmet, Sarajevo 2010; M. Mitrović, Etničko čišćenje kao strategija država na prostoru bivše SFRJ, „Tokovi istorije. Časopis Instituta za noviju istoriju Srbije" 2005, br. 1-2; N. Barić, Je li 1995. godine Hrvatska počinila "etničko čišćenje” Srba?, „Časopis za suvremenu povijest” 2004, god. 36, br. 2; D. Marijan, op. cit., a także pozycję brytyjskiego dziennikarza i analityka wydarzeń z obszaru m.in. Bałkanów Marcusa Tannera: M. Tanner, Croatia. A Nation Forged in War, New Haven-London 1997. 
na rozbieżnościach w postrzeganiu tego wydarzenia. W konkluzji znajdują się wnioski i próba uzasadnienia odpowiedzi na zadane we wstępie pytanie.

\section{Zasadnicze trudności badawcze}

Podjęcie badania tej tematyki nastręcza kilka zasadniczych trudności. Podstawowa i najogólniejsza wynika z faktu spojrzenia na proces rozpadu (rozbicia) Jugosławii, który przez bardzo długi czas (w trakcie i po wojnie) ukazywał w uproszczonym obrazie w zasadzie wyłączną odpowiedzialność Serbów - za rozpad kraju, podjęcie inicjatywy działań zbrojnych wobec pozostałych bezbronnych narodów; popełnianie zbrodni oraz dokonywanie czystek etnicznych. Nie sposób nie zgodzić się z niektórymi z tych zarzutów, zwłaszcza dotyczacymi zbrodni, jednak nawet dzisiaj można spotkać się z ujęciem, które obarcza Serbów wyłączną odpowiedzialnością za te czyny. W takiej sytuacji trudno było (i jest nadal) pisać o serbskich ofiarach podczas wojen. Owszem, w ostatnich latach można spotkać się z coraz większą ilością publikacji mówiących wprost o zbrodniach popełnianych przez wszystkie strony walczące w wojnach jugosłowiańskich, jednak w większości z nich mówi się bardzo oględnie o serbskich ofiarach wojny, w sposób lakoniczny kwitując wydarzenia, w których to właśnie Serbowie stali się ofiarami. Kontrastuje to z wnikliwa analizą tematu w przypadku pozostałych ofiar, zwłaszcza muzułmańskich. Dokonując dość kontrowersyjnego (ale pojawiającego się w chorwackich i serbskich opracowaniach) zestawienia, można zauważyć, że na temat zbrodni popełnionej przez oddziały serbskie w Srebrenicy (w lipcu 1995 r.) powstają filmy, zarówno dokumentalne, jak i sfabularyzowane, książki, istnieje bogata publicystyka, ukazujacca wydarzenie 
w jednoznacznym świetle, którego wiarygodności nikt nie podważa ${ }^{10}$. Z kolei, analizując przypadki zbrodni popełnianych na Serbach w Bośni i Hercegowinie oraz w Chorwacji, należy w doborze źródeł pomijać najlepiej te serbskie, aby uniknąć zarzutu tendencyjności (na co narażone są w zasadzie wszystkie opracowania, przedstawiające zasadność serbskich interesów podczas wojen jugosłowiańskich).

Kolejna trudnościa jest fakt, że racje chorwackich Serbów, początkowo uwzględnione, nie zostały ostatecznie uznane przez międzynarodową opinię publiczna. Ta akceptuje fakty dokonane przez armię chorwacką w 1995 r. ${ }^{11}$ Podnoszenie ich z pewnością implikowałoby zarzut poparcia dla wielkoserbskich idei (zarzut wielkochorwackich tendencji był i jest poruszany przez badaczy wręcz śladowo). Kwestia postrzegania Serbów jako czynnika konfliktogennego wpłynęła również na rozbieżności w ujmowaniu „Oluji”, nawet wśród zachodnich polityków, którzy byli zaangażowani w ówczesne wydarzenia na Bałkanach.

Innym problemem są źródła do tych, stosunkowo nowych, wydarzeń. Istnieje duża ilość dokumentów, które nie dają jednak pełni obrazu wydarzeń lub, co więcej, mogą powodować problemy interpretacyjne (jak np. tzw. transkrypty briońskie, o których będzie mowa poniżej). Publikowane wspomnienia lub wywiady z politykami i ważnymi postaciami, związanymi

${ }^{10}$ Informacje nt. Srebrenicy, które pogłębiają kontekst całego wydarzenia, np. poszerzając listę motywów serbskiego dowództwa (bynajmniej nie negując samego popełnienia zbrodni na tysiącach Muzułmanów/Bošnjaków) nie jest w zasadzie szerzej znana.

${ }^{11} \mathrm{Na}$ te obszary wprowadzono w $1992 \mathrm{r}$. siły pokojowe ONZ - UNPROFOR (przekształcone potem w UNCRO), które miały tam stacjonować, dopóki kwestia serbska w Chorwacji nie zostanie rozwiązana, co mogło wskazywać na fakt, że racje Serbów początkowo były uznawane przez tzw. wspólnotę międzynarodowa, przynajmniej w jakimś zakresie. 
z wydarzeniami, kreują wciąż pożądane obrazy zdarzeń, podobnie jak opowieści naocznych świadków. Powstają reportaże, które podważane są jako źródło informacji - z punktu widzenia badań naukowych. Wiele zawartych w nich stwierdzeń jest ze sobą sprzecznych ${ }^{12}$.

Z kolei główni aktorzy sceny wojennej (politycy i wojskowi), włącznie z aktualnie sądzonymi przez Międzynarodowy Trybunał Karny dla byłej Jugosławii (ICTY) w Hadze, nie spisuja i nie wydaja swoich wspomnień, zawierajacych niekorzystne dla nich (z prawnego punktu widzenia) informacje. Wychodzą natomiast takie, które sa ideologicznym przesłaniem lub maja po prostu uniewinnić osobę w oczach opinii publicznej (np. publikacje dowódcy wojsk serbskich w Bośni i Hercegowinie gen. Ratko Mladicia) ${ }^{13}$.

\section{Geneza operacji ,Oluja”}

W sierpniu 1990 r. Serbowie, mieszkajacy na obszarze Chorwacji, wówczas składowej Socjalistycznej Federacyjnej Republiki Jugosławii (SFRJ), ogłosili w Kninie powstanie autonomicznego obszaru o nazwie Krajina (do końca 1990 r. obszar autonomii był powiększany o inne terytoria zamieszkane przez Serbów). Była to odpowiedź na wybory w tej republice, w których zwyciężyła Chorwacka Wspólnota Demokratyczna (HDZ) Franjo Tuđmana, a także na wprowadzenie nowej republikańskiej konstytucji. Serbowie zostali w niej sprowadzeni do statusu mniejszości narodowej. Obawiali się, że ogłoszenie niezależności Chorwacji od państwa jugosłowiańskiego będzie oznaczało restaurację zasad panujacych

${ }^{12}$ M. Mitrović, op. cit., s. 189.

${ }^{13}$ M. Bjelajac, O. Žunec, op. cit., s. 230. 
w Niezależnym Państwie Chorwackim (NDH) z czasów II wojny światowej. Przekonanie to było w dużej mierze efektem propagandy politycznej, prowadzonej przez późniejszych włodarzy poszczególnych republik jugosłowiańskich. Wykorzystując chylący się ku upadkowi system socjalistyczny, rozwijali oni nowe idee narodowe, nacechowane jednoznacznie retoryka nacjonalistyczną. Zgodnie z nią, właśnie w niezależnej Chorwacji miał powrócić proceder prześladowania Serbów, co potwierdzała postawa części chorwackich radykałów, jawnie nawiązujących do tradycji faszystowskich ustaszy. Ponadto, mające od jakiegoś czasu miejsce szykany wobec Serbów, zwalnianie ich z pracy i inne praktyki (opisane poniżej), uzasadniały dodatkowo te obawy. Z kolei na obszarach, na których przeważali Serbowie, w ten sam sposób traktowano przedstawicieli ludności chorwackiej. Chorwaci zaś obawiali się, określanych wówczas popularnym hasłem ambicji wielkoserbskich, które mogłyby pozbawić ich części terytorium państwa (chodziło właśnie o obszar, na którym Serbowie ogłosili autonomię). Te przyczyny były jednymi z podstawowych, które pogłębiały konflikt serbsko-chorwacki, doprowadzając do starć zbrojnych już w 1990 r. $^{14}$

Do eskalacji napięcia doszło latem 1991 r., po ogłoszeniu przez Chorwację i Słowenię niezależności od SFRJ. Przyczynił się do tego udział Jugosłowiańskiej Armii Ludowej (JNA), która wystapiła przeciwko jednostronnemu odłączeniu terytoriów chorwackich (i słoweńskich) ${ }^{15}$. Krwawy konflikt militarny trwał do grudnia $1991 \mathrm{r}$. i wstrzymany został pod naciskiem dyplomacji międzynarodowej. Nie przyniósł

${ }^{14}$ M. Mitrović, op. cit., s. 194; zob. też N. Barić, Je li 1995. godine..., s. $444-445$.

${ }^{15}$ JNA była wprawdzie armia, w której służyli przedstawiciele wszystkich narodowości jugosłowiańskich, jednak już w tym czasie przeważali w niej Serbowie. 
jednak definitywnego rozstrzygnięcia kwestii spornych obszarów. Chorwacja funkcjonowała już jako niepodległe państwo, zaakceptowane przez tzw. wspólnotę międzynarodowa. Serbowie chorwaccy, nie czekając na dalsze rozstrzygnięcia, ogłosili 21 grudnia 1991 r. powstanie Republiki Serbskiej Krajiny, ze stolica w Kninie, jako odpowiedzi na jednostronne odtaczenie Chorwacji od SFRJ, majqca na celu ochrone praw ludności serbskiej, przeobrażonej tym aktem $w$ mniejszość narodowq ${ }^{16}$.

Plan Cyrusa Vance'a z grudnia 1991 r., przewidujacy przerwanie walk na obszarze Chorwacji, wprowadzał Siły Ochronne Narodów Zjednoczonych (UNPROFOR), tworząc na spornych terytoriach strefy (United Nations Protected Areas, UNPAs) ${ }^{17}$. Powstały tam, gdzie Serbowie stanowili większość

${ }^{16}$ W jej skład wchodziły następujące terytoria: Północna Dalmacja, Lika, Kordun, Banija, Zachodnia Slawonia, Wschodnia Slawonia, Baranja i Zachodni Srem, w sumie $17028 \mathrm{~km}^{2}$. Nie na każdym obszarze RSK serbska ludność stanowiła większość. Podczas gdy w Baniji, Kordunie czy wschodniej Lice liczyła ponad 69\%, w Zachodniej Slawonii 57\%, w północnej Dalmacji 55\%, to we Wschodniej Slawonii tylko 35\%. Niejednokrotnie sytuacja wyglądała w ten sposób, że w miejscowościach, gdzie Serbowie nie stanowili większości, jak np. we Wschodniej Slawonii, po utworzeniu Republiki Serbskiej Krajiny wypędzano stamtąd Chorwatów, których własność przejmowali serbscy uchodźcy, powracający na te obszary po jesiennej chorwackiej ofensywie $1991 \mathrm{r}$. Z kolei Momčilo Mitrović pisze o osiedlaniu Serbów w Baranii i Zachodnim Sremie, skąd przemieszczano Chorwatów do Chorwacji (przesiedlano ich również z obszarów północnej Bośni, zamieszkanej w większości przez Serbów). Czynności te określano w tamtym czasie mianem humanitarnych przesiedlen. W ich wyniku obszar RSK zamieszkiwało 91\% Serbów, 7\% Chorwatów i 2\% przedstawicieli innej narodowości, M. Tanner, op. cit., s. 277; M. Mitrović, op. cit., s. 182, 197; Republika Srpska Krajina, http://www.srpskapolitika.com/krajina/link1.html (dostęp 5 V 2013).

${ }^{17}$ Former Yugoslavia - UNPROFOR, http://www.un.org/en/peacekeeping/missions/past/unprof_p.htm (dostęp 6 VII 2014). 
mieszkańców lub byli najliczniejszą grupa narodowa. Obszary, które znajdowały się w jej granicach, ale były pod kontrola JNA, nosiły miano różowych stref (pink zones). Planowano $\mathrm{z}$ obu tych stref wycofać oddziały armii jugosłowiańskiej, obszar zdemilitaryzować i umożliwić powrót około 250 tys. uchodźców. Zagrzeb i Belgrad zaakceptowały ów plan, jednak władze RSK nie. Ostatecznie premier RSK, Milan Babić, został zmuszony do podpisania go (twierdził nawet, że użyto przeciwko niemu groźby zamachu). Istotny był fakt, że nie określono, kto miał sprawować kontrolę nad tym obszarem, co pozostawiło władzę nad terytorium RSK w rękach serbskich. Tym samym przynależność tego terenu stała się kwestią otwarta, dając nadzieję Serbom na uzyskanie niezależności od Zagrzebia i możliwość przyłączenia się do Republiki Serbii ${ }^{18}$. Mimo to nie mieli oni zaufania do ONZ, a nawet - jak twierdzi chorwacki badacz Davor Marijan - w późniejszej fazie wojny uważali, że żołnierze tej organizacji byli nastawieni prochorwacko ${ }^{19}$.

Z kolei jednym z powodów ciepłego przyjęcia ONZ przez Chorwatów było przekonanie, że pomoże ona, zgodnie z założeniem, w: powrocie chorwackich uchodźców na tereny objęte jej protektoratem (którzy uciekli z tych obszarów lub zostali wypędzeni przez Serbów) ${ }^{20}$; demilitaryzacji sił serbskich; reintegracji ziem pod władzą Zagrzebia. Założenia te nie zostały

${ }^{18}$ Jeszcze w tym czasie jako składowej SFRJ, której koniec ogłoszono nie po raz pierwszy i ostatni w grudniu 1991 r.; od kwietnia 1992 r. Serbia wraz z Czarnogórą utworzyły Federacyjną Republikę Jugosławii, M. Tanner, op. cit., s. 279.

${ }^{19}$ Ibidem, s. 279-280; D. Marijan, op. cit., s. 40, 129, 138.

${ }^{20}$ Szacuje się, że do grudnia 1991 r. w Chorwacji znalazło się około pół miliona chorwackich uchodźców z ziem zamieszkałych przez Serbów (które będą tworzyć Republikę Serbską Krajinę, wraz z Zachodnią Slawonia, Baranią i Sremem). Więcej nt. wypędzeń Chorwatów z obszaru RSK zob. N. Barić, Srpska pobuna u Hrvatskoj 1990.-1995., Zagreb 2005, s. 371 i nast. 
zrealizowane w okresie od 1992 do 1995 r., co więcej, strona chorwacka wysuwała zarzuty, że we Wschodnim Sektorze (Wschodnia Slawonia) obecni tam Rosjanie i Ukraińcy z sił pokojowych ONZ „bratali” się z Serbami z Vukovaru, nie przeprowadzajac operacji ochraniajacych powrót Chorwatów na te obszary. Prezydent Chorwacji F. Tuđman mimo wszystko miał nadzieję, że uda mu się użyć środków dyplomatycznych, by nie pozostawić tego regionu w serbskich rękach ${ }^{21}$.

Istnienie Republiki Serbskiej Krajiny pogłębiało problem i tak trudnego położenia Serbów w innych częściach państwa chorwackiego, wobec których prowadzono politykę dyskryminacyjną na zasadzie odpowiedzialności zbiorowej. Problem ten był nagłaśniany m.in. przez serbskie ugrupowanie Milorada Pupovaca ${ }^{22}$, które podkreślało trudność egzystencji swych rodaków poza RSK. Jednak Serbom współpracującym na płaszczyźnie politycznej z władzami chorwackimi trudno było reagować w konstruktywny i akceptowalny dla wszystkich zaangażowanych stron sposób, również ze względu na brak relacji dyplomatycznych pomiędzy Zagrzebiem i Belgradem. W efekcie tego prowadzono antyserbską politykę w Chorwacji oraz antychorwacką w Serbii (w ramach SRJ). Chorwaccy Serbowie spotykali się z szykanami, wynikajacymi z oskarżeń o doprowadzenie do wybuchu wojny domowej. Wiele takich osób nie wytrzymało presji, atmosfery i przemocy psychicznej, polegajacej na stosowaniu wyzwisk, wymuszaniu emigracji, czy telefonów z pogróżkami. Dochodziło również do morderstw na ludności serbskiej, np. w Zagrzebiu, Sisaku, Osijeku, Splicie czy Zadarze. W latach 1991-1995 wyjechało - w związku z tą sytuacją - około 200 tys. osób, a około 2-3 tys. domów zostało zniszczonych ${ }^{23}$.

${ }^{21}$ D. Marijan, op. cit., s. 129; M. Tanner, op. cit., s. 281.

22 Milorad Pupovac - chorwacki filolog, lingwista i polityk, który w 1991 r. poparł odłaczenie Chorwacji od SFRJ.

${ }^{23}$ M. Tanner, op. cit., s. 282-283. 
Wyjeżdżali także Serbowie z Republiki Serbskiej Krajiny, kierując się głównie do Serbii. Była to emigracja na miarę exodusu, o czym pisały m.in. media belgradzkie we wrześniu 1992 r., jako główną przyczynę podając ekstremalną korupcję krajińskiej władzy. Powodem mógł być również brak skutecznego jej działania w różnych częściach RSK, w których - jak przyznawali żołnierze ONZ, monitorujący władze publiczne - panowała po prostu anarchia. Dodatkowymi przyczynami wyjazdów były: brak pracy, zamierająca gospodarka (władze Krajiny miały nadzieję na wysokie dochody z turystyki w parku plitwickim, ale ta, wskutek wybuchu wojny w Bośni i Hercegowinie, zamierała, podobnie jak na chorwackim wybrzeżu). Powodem wyjazdów była również perspektywa pozostania Krajiny w ramach państwa chorwackiego. Wprawdzie miała ona otrzymać autonomię, jednak mieszkający na jej obszarze Serbowie musieliby pogodzić się ze statusem mniejszości narodowej, co - pod wpływem propagandy - kojarzyło się wyłącznie z negatywnymi aspektami ${ }^{24}$.

$\mathrm{Na}$ początku stycznia 1995 r. F. Tuđman zarzucił wojskom ONZ wspieranie Serbów, co miało być przyczyną odmówienia przedłużenia mandatu UNPROFOR, wygasającego końcem marca ${ }^{25}$. W tym samym czasie wypracowano założenia tzw. Planu Z-4 ${ }^{26}$, majacego być pokojowym porozumieniem między władzami chorwackimi a Serbami z Republiki Serbskiej Krajiny. Przewidywał on m.in. powrót wszystkich uchodźców oraz znaczna autonomię dla obszaru, w którego sktad wchodzito 11 matych $i$ nierozwiniętych gospodarczo

${ }^{24}$ Ibidem, s. 282.

${ }^{25}$ W. Walkiewicz, Jugosławia. Państwa sukcesyjne, Warszawa 2009, s. 273 .

${ }^{26}$ Plan Z-4 został opracowany przez tzw. mini-grupę kontaktowa, w skład której wchodzili przedstawiciele Stanów Zjednoczonych, Rosji, a także Francji i Niemiec (reprezentujących Unię Europejska). 
gmin wokót Gliny i Knina, co stanowiło zaledwie około 1/3 terytorium kontrolowanego w tamtym czasie przez RSK.

W opinii chorwackiego historyka Nikicy Baricia, plan ten dawał nie tyle szeroką autonomię, co tworzył w zasadzie państwo w państwie. Chorwackie władze zaakceptowały projekt, jednak Serbowie nie przyjęli go w tej formie i domagali się dalszych negocjacji oraz zrezygnowania przez Chorwatów z veta wobec przedłużenia mandatu UNPROFOR ${ }^{27}$. Zasadnicza kwestia, według serbskiego badacza Mihajlo Vučinicia, było zbyt duże okrojenie obszaru RSK oraz brak zapewnienia - w tamtym momencie - ochrony ludności serbskiej ze strony $\mathrm{ONZ}^{28}$.

Według emerytowanego jugosłowiańskiego admirała Branko Mamuli, sami Chorwaci nie chcieli uczynić zbyt dużych ustępstw w tym planie na rzecz Serbów, zaś jego odrzucenie stanowiło pretekst do przeprowadzenia planowanych już od jakiegoś czasu operacji wojskowych. Podobną opinię wyraził brytyjski dyplomata David Owen, według którego w tym politycznym dialogu żadna ze stron nie była gotowa do kompromisu, a większe konsekwencje w przypadku braku ustępstw ponosili Serbowie. Chorwaci zostali zwycięzcami, co osiagnęli - w ocenie Owena - dzięki ryzykownym prowokacjom wobec Serbów ${ }^{29}$.

${ }^{27}$ Ostatecznie sily pokojowe ONZ pozostały na obszarze Chorwacji po lutym 1995 r. pod zmienioną nazwą UNCRO.

${ }^{28}$ М.М. Вучинић, Грађански рат у Хрватској 1991-1995, Београд 2004, s. 174.

${ }^{29}$ Owen wymienia najpierw groźbę wstrzymania mandatu ONZ, co miało przestraszyć przywódcę Serbów chorwackich, Milana Marticia, i sprowokować go do wprowadzenia blokady ekonomicznej; prowokacją były też wspomniane rozmowy wokół planu Z-4. Według brytyjskiego negocjatora, Tuđman pilnie obserwował błędy Serbów, aby znaleźć pretekst do usprawiedliwionego uderzenia na Krajinę, N. Barić, Je li 1995. godine..., s. 459; D. Owen, Balkan Odyssey, San Diego-New York 1995, s. 327, 355; zob. też M. Waldenberg, Rozbicie Jugostawii. Od separacji Stowenii 
1 maja 1995 r. rozpoczęła się, bez uprzedzenia wojsk serbskich, operacja o nazwie „Bljesak” („Błysk”), która obejmowała swoim zasięgiem Zachodnią Slawonię. Chorwackie oddziały w kilka godzin opanowały rejon Okučani i Starej Gradiški. Wojska serbskie uciekły (wraz z cywilami) do północnej Bośni. Szacuje się, że podczas tej operacji co najmniej połowa mieszkańców opuściła swoje domostwa. ONZ oskarżyła Chorwację o dokonanie zbrodni wojennych, jednak później wycofała się z tego, co powinno wzbudzać kontrowersje. Według serbskiego historyka Mile Bijelajaca oraz chorwackiego socjologa Ozrena Žuneca, chorwackie sity podczas operacji „Bljesak” nie dokonaty zbyt wielu [podkr. M. K.-W.] czynów tamiacych prawa człowieka. Natomiast N. Barić zaznaczył, że władze chorwackie wystosowały apel do serbskiej ludności, gwarantując cywilom prawa obywatelskie, zaś żotnierzom zastosowanie ustawy o amnestii, pod warunkiem złożenia broni. Wszystkim, którzy chcieli opuścić Chorwacje umożliwiano swobodne i spokojne odejście ${ }^{30}$.

O umożliwieniu cywilom opuszczenia Zachodniej Slawonii w celu udania się na obszar Bośni i Hercegowiny pisał również chorwacki historyk D. Marijan. Natomiast Barić przytaczał wspomnienia serbskiej socjolożki i polityka, Vesny Pešić, która była świadkiem dobrowolnego opuszczania ziem chorwackich przez Serbów, mimo apeli serbskich polityków (Veljko Đakuli) o pozostanie tam ${ }^{31}$.

do wojny kosowskiej, Warszawa 2003, s. 141; M. Bjelajac, O. Žunec, op. cit., s. 248; D. Marijan, op. cit., s. 59.

${ }^{30}$ Można zaznaczyć, że apel ten był czasowo ograniczony, N. Barić, Je li 1995. godine..., s. 447.

${ }^{31}$ Ibidem; D. Marijan, op. cit., s. 48; Rat i manjine. Rat u Hrvatskoj 1991-1995. Nezavisnost $i$ sudbina manjina 1991-1992, prir. Lj. Despotović, D. Gavrilović, Novi Sad 2007, s. 44. 
Z kolei serbski badacz Stanko Nišić podał, że kolumny uchodźców były bombardowane przez Chorwatów, zaś na obszary zajęte przez chorwackie wojska zabroniono wstępu obserwatorom międzynarodowym i przedstawicielom organizacji humanitarnych. Marek Waldenberg, powołując się na dane władz Krajiny, przytoczył liczbę 400 zabitych $^{32}$.

Ostatecznie niezbyt wiele czynów tamiacych prawa człowieka zostało zinterpretowane przez ONZ jako nie majacce miejsca w ogóle, bo jak inaczej można by tłumaczyć wycofanie oskarżenia? W każdym razie operacja „Bljesak” jako wojskowe wyzwolenie części Zachodniej Slawonii ${ }^{33}$ została zakończona sukcesem. W odwecie Serbowie dokonali ataku rakietowego na Zagrzeb (2 i 3 maja 1995 r.), w wyniku którego śmierć poniosło 7, a rannych zostało 200 osób. To z kolei wywołało konsekwencje wobec władz RSK ${ }^{34}$.

Pod koniec lipca Zgromadzenie Ogólne ONZ wydało rezolucję 43/49 pod znamiennym tytułem Sytuacja na okupowanych [podkr. M. K.-W.] terytoriach chorwackich, wskazując, że obszary, znajdujacce się pod kontrolą serbska, były ziemiami okupowanymi. A to stawiało pod znakiem zapytania racje i oczekiwania Serbów co do tych terytoriów i powinno było być dla nich ostrzegawczym znakiem, aby zmienili swoje nieustępliwe dotąd stanowisko ${ }^{35}$.

${ }^{32}$ C. Нишић, op. cit., s. 173; M. Waldenberg, op. cit., s. 142.

${ }^{33}$ N. Barić, Je li 1995. godine..., s. 446.

${ }^{34} \mathrm{~W}$ wyniku tego ostrzału prezydent RSK M. Martić został oskarżony o zbrodnie wojenne i był ścigany przez ICTY, M. Bjelajac, O. Žunec, op. cit., s. 249; M. Tanner, op. cit., s. 294.

${ }^{35}$ M. Bjelajac, O. Žunec, op. cit., s. 250. 


\section{Problemy z interpretacją operacji „Oluja”}

Według ustaleń poczynionych na Brioni 31 lipca 1995 r., kolejna operacja wojsk chorwackich, tym razem pod kryptonimem „Oluja”, miała być również przeprowadzona w błyskawicznym tempie (celem: zajęcie ośrodków dowódczych i komunikacyjnych) i, podobnie jak w przypadku operacji „Bljesak”, oczekiwano, że w momencie wkroczenia wojsk chorwackich ludność serbska opuści obszary RSK. Według Petera Galbraitha, ówczesnego ambasadora amerykańskiego w Chorwacji, istniało porozumienie między F. Tuđmanem a tzw. wspólnotą międzynarodowa, która dawała wolna rękę Chorwatom w $z a$ prowadzeniu porzqdku w Krajinie - pod warunkiem, że operacja będzie trwała szybko i nie dojdzie podczas niej do zbrodni na ludności cywilnej. Ze strony serbskiej pojawiły się w późniejszym czasie zarzuty, że Galbraith dowiedział się o zamiarze przeprowadzenia operacji dwa tygodnie przed jej rozpoczęciem i nie podją $\mathrm{w}$ tej sprawie żadnych działań. $\mathrm{W}$ istocie mogło to wyglądać na amerykańskie przyzwolenie na jej podjęcie. Co więcej, w przygotowywaniu taktycznego instruktażu oraz planu operacyjnego pomagali emerytowani żołnierze amerykańscy z błogostawieństwem administracji Billa Clintona. Nie było to niczym zaskakującym, uwzględniając fakt, że w 1994 r. Stany Zjednoczone oraz Chorwacja podpisały porozumienie o wzajemnej militarnej współpracy między ich siłami zbrojnymi, uwzględniające amerykańskie programy treningowe ${ }^{36}$.

Prezydent RSK Milan Martić już kilka miesięcy przed planowaną operacją oświadczył, że międzynarodowa wspólnota dała gen. Tudmanowi do zrozumienia, że wesprze jego

${ }^{36}$ Croatia. Impunity for Abuses...; M. Bjelajac, O. Žunec, op. cit., s. 251-253; por.: A. Nazor, op. cit., s. 15; D. Kovačević, Kavez. Krajina u dogovorenom ratu, Beograd 2003, s. 100; Rat i manjine..., s. 50. 
imperialistyczne zapędy do zajęcia serbskich etnicznie ziem ${ }^{37}$. Mimo to był wciąż przekonany, że w razie ataku otrzyma wsparcie wojsk serbskich z Bośni i SRJ. Co więcej, stwierdził, że Republika Serbskiej Krajiny istnieje już piaty rok. Tego nie można nie dostrzegać, ani ignorować. Ten fakt musi uszanować także Rada Bezpieczeństwa i Nowy Jork, Belgrad i Zagrzeb, UNPROFOR $i$ cata wspólnota międzynarodowa ${ }^{38}$.

Prezydent Chorwacji F. Tuđman zgodził się na kontynuację rozmów w sprawie planu Z-4 z przedstawicielami Knina w Genewie 3 sierpnia. Był to polityczny zwód, którym w ten sposób zakamuflował swoje prawdziwe plany rozpoczęcia operacji wojskowej dzień po negocjacjach ${ }^{39}$.

Można również postawić pytanie, dlaczego Tuđman nie chciał rzeczywiście rozwiązać kwestii serbskiej drogą dalszych negocjacji planu Z-4? Najprawdopodobniej wiązało się to z oczekiwaniami chorwackiego przywódcy, który chciał, aby odsetek Serbów po wojnie był co najwyżej na poziomie 5\% (Ž. Juzbašić podaje nawet $3-4 \%)^{40}$. Potwierdził to biograf Tuđmana Darko Hudelist, który pisał o tym, że politykowi

${ }^{37}$ R. Bilski, op. cit., s. 77.

${ }^{38}$ Warto zauważyć, że wśród władz RSK istniał konflikt na linii prezydent-premier. W opinii P. Galbraitha prezydent M. Martić odrzucał polityczne rozwiązania problemu Krajiny oraz perspektywę ewentualnej koegzystencji z Chorwatami w ramach jednego państwa, zaś premier M. Babić był otwarty na te koncepcje, miał jednak mniejszy wpływ na politykę RSK, a przede wszystkim nie miał władzy nad wojskami, ibidem; The Cases. The Transcripts, 25 VI 2003, International Criminal Tribunal for the former Yugoslavia, http://www.icty.org/x/cases/slobodan_milosevic/trans/ en/030625ED.htm; The Cases. The Transcripts, 26 VI 2003, International Criminal Tribunal for the former Yugoslavia, http://www.icty.org/x/cases/ slobodan_milosevic/trans/en/030626IT.htm (dostęp 2 VII 2014).

${ }^{39}$ M. Bjelajac, O. Žunec, op. cit., s. 251-252; D. Marijan, op. cit., s. 410; Rat $i$ manjine..., s. 48.

${ }^{40}$ M. Bjelajac, O. Žunec, op. cit., s. 257; Ž. Juzbašić, op. cit., s. 40. 
temu zależało na państwie narodowym, w którym nacją konstytucyjną będą tylko Chorwaci. Za jeden z głównych problemów uważał właśnie zmniejszenie odsetka Serbów z ponad $12 \%$ na co najwyżej $5 \%$. Wydawało się to logiczne i na pewno było pożądane przez władze chorwackie. Oto liczebność Serbów, nie przekraczająca 5\% ogółu mieszkańców, pozwoliłaby na niewyróżniające się zaszeregowanie ich do mniejszości narodowych Chorwacji. Co więcej, nie byłoby wówczas podstaw nadawania im przywilejów, np. w postaci autonomii terytorialnej. To potwierdzałoby z kolei przypuszczenia, że celem działań Chorwatów podczas planowanej operacji wojskowej było usunięcie Serbów z obszaru Krajiny (przynajmniej pożqdanej liczby). Były burmistrz Knina - Drago Kovačević - stwierdził wprost, że chorwacki prezydent spełnił misję historyczna, jaką było oczyszczenie Chorwacji z Serbów. Ambasador USA P. Galbraith z kolei zauważył, że, być może, Tuđman nie miał planu wypędzenia Serbów, jednak kiedy odeszli, nie chciał, żeby wrócili. Mogło to świadczyć o hipokryzji tego polityka, apelującego do Serbów o pozostanie w domach w momencie podjęcia działań wojskowych ${ }^{41}$.

Po rozpoczęciu operacji „Oluja” 4 sierpnia M. Martić nakazał ewakuację ludności serbskiej. Istnieją też opinie, że fałszywe informacje o tym rozpowszechniali (również w postaci ulotek) sami Chorwaci, którzy chcieli, aby Serbowie opuścili Krajinę i udali się dokqdkolwiek z terenów Chorwacji, co w praktyce oznaczało BiH lub Serbię. Chorwackie źródła donosiły także, że - w obliczu zbliżających się działań wojennych - ewakuację podjęto już wcześniej, przerzucajac autobusami do Serbii tysiace kobiet $i$ dzieci ${ }^{42}$. Przyczyną opuszczania

${ }^{41}$ M. Mitrović, op. cit., s. 181; zob. też: C. Нишић, op. cit., s. 196; Rat i manjine..., s. 57; D. Kovačević, op. cit., s. 103.

${ }^{42}$ M. Bjelajac, O. Žunec, op. cit., s. 252; D. Marijan, op. cit., s. 375; D. Kovačević, op. cit., s. 93. 
obszaru Krajiny, zarówno wcześniej, jak i bezpośrednio przed operacja, była też wojna psychologiczna, jaką rozpoczęli Chorwaci. W mediach zamieszczali oni wiadomości o dużych konwojach serbskich cywili, opuszczających poszczególne terytoria. Pojawiały się również, skierowane pod adresem Serbów, informacje o możliwości swobodnego wyjazdu z Krajiny (dotyczyło to wyłącznie cywili) ${ }^{43}$.

Zgodnie ze stanowiskiem chorwackim, opuszczenie obszaru RSK przez Serbów było dobrowolnym aktem, do którego nie przyczyniła się ofensywa wojsk chorwackich. Co więcej, według M. Tannera, po rozpoczęciu operacji „Oluja” Tuđman wezwał wojska Republiki Serbskiej Krajiny do złożenia broni, władze w Kninie do poddania się, zaś ludność cywilną do pozostania w domach - ich prawa miały zostać zagwarantowane. Tanner pisze też o ucieczce wojska serbskiego i zdegenerowanych władz RSK wraz z cywilami, co pozwoliło wyzwolić Krajinę praktycznie bez wystrzału. Podobnie o operacji pisał amerykański dyplomata Richard Holbrooke, według którego Serbowie niespodziewanie poddali miasto bez walki (chodziło o Knin ${ }^{44}$. Istnieja krótkie filmy dokumentalne oraz zdjęcia, potwierdzające brak chorwackiej niechęci wobec Serbów oraz pokazujące policjantów, którzy podchodzili do serbskich pojazdów, namawiając ludzi, żeby wrócili do swoich domów. W raporcie Helsińskiej Fundacji Praw Człowieka można jednak znaleźć informacje, że były to aranżowane sceny, filmowane na potrzeby propagandowe. Trudno byłoby $\mathrm{w}$ istocie uwierzyć, że ludność chorwacka naprawdę żegnała kolumny serbskich uchodźców żywnością i kwiatami, jak to zostało sfilmowane ${ }^{45}$.

\footnotetext{
${ }^{43}$ K. Дел Понте, op. cit., s. 292; zob. też C. Нишић, op. cit., s. 142-143.

${ }^{44}$ M. Tanner, op. cit., s. 297, 301.

${ }^{45}$ Croatia. Impunity for Abuses..., s. 11.
} 
Przejęcia Krajiny bez oddania strzału bardzo dobrze wpisywałoby się w obraz zgodnej z prawem, wręcz humanitarnej, ofensywy. Jednak te doniesienia stały w sprzeczności z innymi faktami, przytaczanymi - paradoksalnie - również m.in. przez M. Tannera. Według niego, czego nie spalili Serbowie w 1991 r., spalili Chorwaci w 1995 r., dlatego, że byto serbskie. O taktyce „spalonej ziemi”, majacej na celu uniemożliwienie powrotu, pisał także Ž. Juzbašić. Jeśli chodziło o informacje dotyczace ucieczki wojsk Krajiny, inne źródła podaja, że RSK broniło 37-40 tys. żołnierzy. Również D. Marijan, który dokonał bardzo wnikliwej analizy działań wojskowych podczas tej operacji, opisywał szczegółowo starcia z wojskami RSK ${ }^{46}$.

Odmienny od powyższego obraz przedstawiali także inni badacze, piszacy o intensywnych bombardowaniach m.in. Knina (obleganego dwa dni) i regularnych walkach chorwacko-serbskich. Wśród nich można wymienić: M. Waldenberga, Macieja Kuczyńskiego oraz polskiego reportera, obecnego w tamtych czasach na Bałkanach - Ryszarda Bilskiego. Ponadto o atakach chorwackiej artylerii na cywilne obiekty pisała również Del Ponte ${ }^{47}$.

$\mathrm{Na}$ łamanie praw człowieka przez wojska chorwackie wskazywali w swoich raportach, opublikowanych przez Danutę Gibas-Krzak, polscy żołnierze z sił pokojowych ONZ - UNPROFOR, przekształconych później w Operację Narodów Zjednoczonych Przywrócenia Zaufania w Chorwacji (UNCRO). Informacje na ten temat można znaleźć w raportach

${ }^{46}$ M. Mitrović, op. cit., s. 197; zob. D. Marijan, op. cit., s. 127 i nast.; por.: M. Waldenberg, op. cit., s. 143; M. Tanner, op. cit., s. 301; Ž. Juzbašić, op. cit., s. 248.

${ }^{47}$ Więcej zob.: R. Holbrooke, To End a War, New York 1999, s. 72; M. Waldenberg, op. cit., s. 141; R. Bilski, op. cit., s. 90-91; K. Дел Понте, op. cit., s. 292; zob. też C. Нишић, op. cit., s. 183-185. 
Helsińskiej Fundacji Praw Człowieka. W świetle raportów żołnierzy polskich, stacjonujących na obszarze zamieszkanym przez Serbów, podczas wkraczania wojsk chorwackich i penetrowania przez nich domostw słychać było strzały, zaś budynki były podpalane. Również według danych Helsińskiej Fundacji Praw Człowieka w Chorwacji zostało podpalonych, zdewastowanych i zaminowanych co najmniej 22 tys. domów (Serbowie podaja liczbę 25 tys. $^{48}$ ). Na masową skalę grabiono własność ruchoma, zakłady przemysłowe, domy kultury, niszczono publiczna infrastrukturę, biblioteki i pomniki. Przez kilka kolejnych miesięcy trwała również dewastacja obiektów Serbskiej Cerkwi Prawosławnej, i to mimo dużego zaangażowania chorwackich autorytetów, usiłujących chronić te budowle ${ }^{49}$.

Raport helsiński wspomina o tym, że Serbowie (ale także uciekajacy Chorwaci) byli wprawdzie eskortowani przez siły

${ }^{48}$ „Oluja” zločin koji još traje, „Krajinaforce. Glas krajišnika u egzilu”, http://www.krajinaforce.com/oluja_brijunski_transkripti.html (dostęp 26 VI 2014); zob. też M. Waldenberg, op. cit., s. 148.

${ }^{49}$ Serbowie podaja, oprócz wspomnianej liczby domów, również następujaça listę zniszczeń obiektów nie mających znaczenia strategiczno-militarnego: 13 tys. budynków o przeznaczeniu gospodarczym, 182 domy spółdzielcze, 56 placówek służby zdrowia, 78 cerkwi, 29 muzeów, 181 cmentarzy, 352 placówek handlowych, 96 trafostacji, wszystkie serbskie zakłady przemysłowe, 920 obiektów zabytkowych, 211 obiektów gastronomicznych i 410 zakładów rzemieślniczych. Ponadto żołnierze UNCRO w dniach, gdy rozpoczęła się „Oluja”, zgłaszali napady wojsk chorwackich na ich punkty obserwacyjne. Więcej na ten temat zob.: D. Gibas-Krzak, Operacja „Oluja” $w$ świetle raportów $i$ dokumentów oficerów i podoficerów 2 kompanii piechoty polskiego batalionu UNPROFOR $w$ Chorwacji, [w:] „Na ostrzu miecza stoja nasze sprawy...”. Studia o stużbach specjalnych, wojnie i bezpieczeństwie Polski, Europy i świata. Z okazji 70-lecia profesora doktora habilitowanego Wiesława Wróblewskiego, [red. nauk. A. Aksamitowski, P. Zając], Szczecin 2012, s. 364-378; „Oluja” zločin...; M. Mitrović, op. cit., s. 199; Croatia. Impunity for Abuses..., s. 19. 
chorwackie, jednak niektórzy przemieszczali się wbrew ich woli. Co więcej, raport nadmieniał, że uchodźcy byli atakowani, obrzucani granatami lub bombardowani $w$ różnych miejscach podczas ich ucieczki (oryg. exodusu). Uciekajacy Serbowie byli również napadani przez ludność chorwacka, która obrzucała ich kamieniami, butelkami i innymi rzeczami. Dochodziło także do wywlekania osób z pojazdów i bicia ich (czego konsekwencja były odnotowane przypadki śmierci). Serbom odbierano również siłą samochody ${ }^{50}$. Należy dodać, że część tych incydentów miała miejsce $\mathrm{w}$ obecności żołnierzy ONZ, którzy potwierdzali, że po zdobyciu Knina na ulicach leżała znaczna liczba ciał, a wiele $z$ nich to byty kobiety $i$ dziecisi ${ }^{51}$. Wprawdzie raport odnotowuje, że późniejsze doniesienia obniżały liczby pierwotnie podawane, jednak w kontekście analizowanego problemu istotny pozostał zwłaszcza sam czyn, nie tylko ilość ofiar. Polski reporter, R. Bilski, pisał w 2001 r. o odkrytych masowych serbskich grobach, zarówno w samym Kninie, jak i w okolicach ${ }^{52}$.

Według raportu Helsińskiej Fundacji Praw Człowieka w Chorwacji, opublikowanego w kwietniu 1999 r., tylko na obszarze Sektora Południe, podczas operacji „Oluja” lub w jej wyniku, zabito 526 Serbów, z czego 116 było cywilami. Zgodnie z tym samym raportem, wskutek akcji Chorwatów z obszaru Krajiny uciekło 200 tys. osób, a 110 osób zaginęło. Z danych organizacji Veritas wynika, że podczas „Oluji” zginęło 1959 osób. Ambasador P. Galbraith podczas zeznań w Hadze, w wywiadach, których udzielał zarówno chorwackiej telewizji HTV „Nedeljom u 2", jak i telewizji brytyjskiej, potwierdzil,

${ }^{50}$ D. Marijan, op. cit., s. 112; Croatia. Impunity for Abuses..., s. 9-10, 12; N. Barić, Je li 1995. godine..., s. 455; D. Marijan, op. cit., s. 140; C. Нишић, op. cit., s. 193; D. Kovačević, op. cit., s. 98.

${ }^{51}$ Croatia. Impunity for Abuses..., s. 8; К. Дел Понте, op. cit., s. 292; С. Нишић, op. cit., s. 193.

${ }^{52}$ M. Waldenberg, op. cit., s. 147. 
że czystek etnicznych dokonywały nie regularne wojska chorwackie, a oddziały paramilitarne, które zabijały cywili i paliły domy, żeby uniemożliwić im ewentualny powrót. Podawał liczbę 1990 zabitych osób cywilnych i 350 tys. wypędzonych ${ }^{53}$. Według raportów śledczych ONZ, podczas „Oluji” oraz po niej na co najmniej 150 osobach wykonano egzekucje (co potwierdzał późniejszy akt oskarżenia przeciwko gen. Ante Gotovinie), jednak lokalna organizacja pozarządowa zwiększyła tę liczbę do ponad 700 osób ${ }^{54}$.

Po operacji Chorwatów dochodziło jeszcze do aktów dyskryminacji i wypędzeń Serbów przez kolejne miesiące. Niektórzy z nich wracali nawet po tygodniu od zakończonej ofensywy, lecz byli ponownie wypędzani. Miało się to odbywać za zgodą chorwackich władz państwowych, które ochraniały siły rządowe, dokonujące tych aktów. Wydarzenia te miały być ukrywane przed opinia publiczna. Prokurator Del Ponte stwierdziła, że czystki etniczne na ludności serbskiej w Chorwacji zakończyły się 15 listopada 1995 r. Inne źródła mówią o wiośnie 1996 r. ${ }^{55}$

${ }^{53}$ M.M. Вучинић, op. cit., s. 162; M. Bjelajac, O. Žunec, op. cit., s. 250; U Hrvatskoj Dan pobjede, u Srbiji parastos, „Aljazeera. Balkan”, 4 VIII 2012, http://balkans.aljazeera.net/vijesti/u-hrvatskoj-dan-pobjede-u-srbiji-parastos; P. Pejčić, Srbima pouratka nema, „Večernje novosti online”, 30 XI 2012, http://www.novosti.rs/dodatni_sadrzaj/clanci.119.html:408405-Srbima-povratka-nema; Dokumentaciono Informacioni Centar „Veritas”, http:// www.veritas.org.rs/bilten/ (dostęp $4 \mathrm{~V}$ 2013); zob. też M. Mitrović, op. cit., s. 198; por.: A. Nazor, op. cit., s. 23; D. Marijan, op. cit., s. 411; Rat i manjine..., s. 52; Ž. Juzbašić, op. cit., s. 40.

${ }^{54}$ Croatia. Impunity for Abuses..., s. 2, 8, 22; por.: ibidem, s. 23; The Prosecutor of the Tribunal against Ante Gotovina. Indictment, The International Criminal Tribunal for the Former Yugoslavia, Case no: IT-01-45-I, http://www. icty.org/x/cases/gotovina/ind/en/got-ii010608e.htm (dostęp 18 VI 2014).

${ }^{55}$ Podczas operacji zginęło również 211 chorwackich żołnierzy i policjantów oraz 42 osoby cywilne. W helsińskim raporcie zaznaczono, że nie 
Wizytujący Chorwację we wrześniu 1995 r. John Shattuck z Departamentu Stanu USA, skrytykował egzekucję Serbów (execution of Serbs; o egzekucjach wspominała również Del Ponte) oraz zniszczenie ich własności w trakcie przeprowadzenia operacji. Zachowania te określił mianem zbrodni wojennych. Co więcej, negocjacje Chorwacji z Unią Europejską (UE) zostały zawieszone właśnie z powodu naruszenia klauzuli pełnego poszanowania praw człowieka i demokratycznych pryncypiów ${ }^{56}$.

$$
* * *
$$

Kontrowersje i rozbieżne interpretacje, związane $\mathrm{z}$ operacja „Oluja”, dotyczą kilku zasadniczych pojęć, które determinują ujęcie całej problematyki, rzutującej w zdecydowany sposób na najnowszą historię Chorwacji. Pierwsza kwestia jest związana z tym, czy opuszczenie obszaru Republiki Serbskiej Krajiny było exodusem (względnie ewakuacja lub odejściem) czy też czystka lub wypędzeniem. W źródłach chorwackich przeważa raczej exodus, chociaż sami Serbowie określaja to wydarzenie najłagodniej jako wypędzenie (wygnanie - exilium), ale również jako czystkę

posiadano danych pochodzących z serbskich źródeł. Warto także wspomnieć, że w 1998 r., gdy Chorwacja przejęła kontrolę nad obszarem Wschodniej Slawonii, Baranii i zachodnim Sremem, wyemigrowało stamtąd około 40 tys. Serbów, J. Paszkiewicz, Problem integracji Serbów powracajacych do Chorwacji ze społeczeństwem $i$ strukturami państwa chorwackiego (2000-2005), [w:] Integracja i tożsamość narodowa w Europie Środkowo-Wschodniej na przestrzeni dziejów. Z prac Polsko-Bułgarskiej Komisji Historycznej, red. nauk. E. Znamierowska-Rakk, Warszawa 2007, s. 223; К. Дел Понте, op. cit., s. 293; zob. też C. Нишић, op. cit., s. 170.

${ }^{56}$ Human Rights Watch World Report 1996 - Croatia, UNHCR, The UN Refugee Agency, http://www.refworld.org/docid/3ae6a8b144.html (dostęp 2 VII 2014). 
etnicznq. Słownikowa definicja exodusu wyjaśnia ten termin jako: masowe wyjście, wyjazd skqdś, masowa emigracja; inna mówi nawet o opuszczeniu kraju ojczystego, emigra$c j{ }^{57}$. Exilium jest definiowane jako zmuszenie kogoś do odejścia skadś lub wyprowadzenie skadś jakiejś osoby [...], żeby udata się w określone miejsce $e^{58}$. Z kolei czystka to usuwanie niewygodnych osób z jakichś środowisk metodami nacisków, szantażu itp. ${ }^{59}$ Uwzględniając różnice interpretacyjne w postrzeganiu operacji „Oluja”, zrozumiałe jest stosowanie tych określeń przez każdą ze stron. Exodus nie sugeruje jednoznacznie czyjejśs zewnętrznej ingerencji, przyczyniającej się do emigracji, z kolei zarówno exilium, jak i czystka wyraźnie to stwierdzaja.

Faktem jest, że opuszczenie przez Serbów Krajiny było bezpośrednim skutkiem ofensywy zbrojnej. Z upływem czasu wrażenie ścisłego związku między działaniem wojsk chorwackich a ucieczką Serbów może zostać zatarte na rzecz uwypuklenia czynników politycznych. Te mogłyby sugerować, że Serbowie postanowili opuścić Chorwację np. w wyniku niemożności pogodzenia się z faktem pozostania ziem przez nich zamieszkanych $\mathrm{w}$ granicach republiki chorwackiej. Do takiego wskazania dąży część badaczy chorwackich. Na poparcie tej tezy podaja fakt już wcześniej planowanych przez lokalne serbskie władze ewakuacji ludzi z poszczególnych miejscowości ${ }^{60}$.

${ }^{57}$ Stownik wyrazów obcych $i$ zwrotów obcojęzycznych Władystawa Kopalińskiego, http://www.slownik-online.pl/kopalinski/9B90351FF5CE3878C12565BE0048CAC0.php (dostęp 21 V 2014).

${ }^{58}$ Stownik języka polskiego PWN, http://sjp.pwn.pl/szukaj/wyp\%C4\%99dzenie (dostęp 21 V 2014).

${ }^{59}$ Stownik języka polskiego PWN, http://sjp.pwn.pl/szukaj/czystka (dostęp $21 \mathrm{~V}$ 2014).

${ }^{60}$ N. Barić, Je li 1995. godine..., s. 449-450; zob. też A. Nazor, op. cit., s. 11. 
Kolejną przyczyną podjęcia decyzji o opuszczeniu RSK były obawy przed aktami przemocy, których mogły dopuścić się wojska chorwackie. Ambasador P. Galbraith w zeznaniach podczas procesu przeciwko Slobodanowi Miloševiciowi 25 czerwca 2003 r., odnosząc się do działań chorwackich sił zbrojnych, zaznaczył, że Serbowie uciekali w obawie przed tym, co może ich spotkać ze strony Chorwatów. Dodał, że chorwaccy żołnierze przybywali na obszary zamieszkane przez Serbów z zamiarem ich eksterminacji, jednak tych już tam nie było. Zgodnie z opinią Galbraitha, nie powinno się więc obwiniać Chorwatów o niezrealizowane zamiary ${ }^{61}$. Jest to zgodne $\mathrm{z}$ prawda, ale obawy były uzasadnione, uwzględniając mordy na ludności, która zdecydowała się pozostać na miejscu. Stosowanie taktyki „spalonej ziemi" oraz zabijanie osób, które nie uciekły, mieściło się w kategoriach pojęcia czystki etnicznej.

Wokół interpretacji powyższych pojęć - w kontekście operacji „Oluja” - zderzenie opinii nie ma wyłącznie podziału na chorwacki i serbski punkt widzenia. Podczas gdy stanowisko Serbów jest jednolite w ujęciu tego wydarzenia, to w Chorwacji istnieje głęboki i asymetryczny podział opinii. Większość tamtejszych badaczy postrzega bowiem „Oluję" jako wyzwoleńcza, bohaterską i pozbawioną kontrowersji operację wojskowa. Nieliczni zaś (S. Livada, czy nieco bardziej powściagliwy O. Žunec) wskazywali na zbrodniczy charakter czynów armii, których nie potępiła ani opinia publiczna (nie tylko chorwacka), ani wymiar sprawiedliwości. Krytykowany m.in. przez N. Baricia Livada wskazał też na absurdalność stwierdzeń o dobrowolnej ucieczce. Oświadczył, że teoria o samowypędzeniu jest nie do obrony ${ }^{62}$.

${ }^{61}$ The Cases. The Transcripts, 25 VI 2003...; The Cases. The Transcripts, 26 VI 2003... (dostęp 2 VII 2014).

${ }^{62}$ S. Livada, Etničko čišćenje - zločin stoljeća, Zagreb 1997, s. 96-97. 
Watpliwości co do interpretacji wydarzenia nie mieli z kolei D. Owen czy C. Del Ponte, nazywając operację „Oluja” wprost czystka etnicznq ${ }^{63}$. Była nią także w ocenie części żołnierzy wojsk Narodów Zjednoczonych, stacjonujących w tamtym czasie na obszarze RSK. Świadczy o tym choćby notatka służbowa (a także wspomniane wcześniej raporty wojskowe), sporządzona przez dowódce 2 . kompanii piechoty polskiego batalionu sił pokojowych ONZ: Operacja „Burza” miała za zadanie rozbić sity Serbów i przytaczyć Krajine do Chorwacji oraz dokonać czystki etnicznej ${ }^{64}$. Dowodem na to mogła być również reakcja ONZ i UE, jak i przedstawicieli władz szwedzkich oraz rosyjskich, potępiających działania chorwackie. To, być może, nie miałoby miejsca w przypadku, gdyby Krajina została w istocie zajęta „bez wystrzału”.

Kolejne, zupełnie przeciwstawne ujęcie dotyczy kwestii odpowiedzialności za zbrodnie przez konkretne podmioty. Można odnieść wrażenie, że chorwaccy historycy i politolodzy starają się przedstawić historię niepodległości Chorwacji po 1991 r. jako nieskazitelny obraz, w ramach którego mieszczą się wyłącznie praworządność i bohaterowie. Z głównych aktorów chorwackiej sceny politycznej i wojskowej zdjęta została odpowiedzialność za zbrodnicze aspekty najważniejszej operacji wojskowej. To było w dużej mierze „zasługa” międzynarodowej opinii publicznej. Można postawić pytanie: Czy prezydent F. Tuđman od początku nie zamierzał chronić serbską ludność cywilna, czy też miał nadzieję, że do łamania praw człowieka rzeczywiście nie dojdzie? To drugie oznaczało naiwność, niemożliwą raczej u tak wytrawnego gracza. Przecież zależało mu przede wszystkim na uzyskaniu akceptacji ze strony zagranicznych polityków. Liczyło się tylko

${ }^{63}$ K. Дел Понте, op. cit., s. 292; D. Owen, op. cit., s. 327, 355.

${ }^{64}$ D. Gibas-Krzak, op. cit., s. 364-378. 
przejęcie Krajiny oraz zgoda dyplomatów na zorganizowanie w tym celu akcji. Aktualnie nurtujące jest inne pytanie: Czy Chorwaci byli pewni już wtedy (1995 r.), że nawet w obliczu takiego czynu nie poniosa międzynarodowych konsekwencji? Nie ucierpiał przecież wizerunek Tuđmana, nie ucierpiał wizerunek jego państwa, które wprawdzie było dyscyplinowane na arenie międzynarodowej z powodu choćby swojej polityki mniejszościowej, to jednak nigdy przez dłuższy okres.

Wyłączenie na najwyższym szczeblu odpowiedzialności za zbrodnie objęło również głównych dowódców wojskowych, postrzeganych w Chorwacji jako bohaterowie „wojny domowej”. Najbardziej spektakularny przykład dotyczył A. Gotoviny $^{65}$ i Mladena Markača ${ }^{66}$, którzy jednak byli sądzeni przez ICTY, m.in. za zbrodnie przeciwko ludności serbskiej podczas operacji „Oluja”. Na listę zarzutów składały się prześladowania, morderstwa, grabieże, niszczenie mienia czy okrutne traktowanie. Dodatkowo akt oskarżenia zawierał zarzut uczestnictwa we „wspólnym kryminalnym przedsięwzięciu” [joint criminal enterprise], majacym na celu trwałe usunięcie serbskiej ludności z regionu Krajina ${ }^{67}$, co miało zostać zaplanowane i ustalone w tzw. transkryptach briońskich. Sąd pierwszej instancji skazał Gotovinę na 24 lata więzienia, zaś Markača na 18. Potwierdzenie uczestnictwa $\mathrm{w}$ zbiorowym procederze kryminalnym podważało obraz

${ }^{65}$ Generał pułkownik A. Gotovina był dowódca okręgu wojskowego Split, któremu podlegał obszar działania obejmujący m.in. Knin, Zadar i Šibenik.

${ }^{66}$ Generał pułkownik M. Markač był dowódcą zjednoczonych oddziałów Policji Specjalnej Ministerstwa Spraw Wewnętrznych Republiki Chorwacji.

67 "Operation Storm” (IT-06-90) Gotovina \& Markač. Case Information Sheet, United Nations. International Criminal Tribunal for the former Yugoslavia, http://www.icty.org/x/cases/gotovina/cis/en/cis_gotovina_al_en.pdf, s. 5 (dostęp 18 VI 2014). 
i racje głównych aktorów chorwackiej sceny politycznej i wojskowej. W procesie apelacyjnym oskarżeni zdołali udowodnić, że coś takiego, jak wspólne kryminalne przedsięwzięcie, nie istniało, zaś przebieg operacji obejmował działania wojskowe zgodne z zasadami sztuki wojennej ${ }^{68}$. W ten sposób strona chorwacka wykazała, że działania wojskowe, mające na celu odzyskanie obszarów RSK, były jak najbardziej zgodne z prawem. Efektem stało się anulowanie wyroków pierwszej instancji i całkowite uniewinnienie obu wojskowych w listopadzie 2012 r. (można dodać, że w 2011 r. uniewinniono gen. Ivana Čermaka - dowódcę korpusu knińskiego Armii Chorwackiej).

Decyzja Trybunału wywołała ogromne wzburzenie serbskich władz i opinii publicznej, dla których wyroki pierwszej instancji były aktem sprawiedliwości, a uniewinnienie - legitymizacja chorwackich zbrodni wojennych w świetle międzynarodowego prawa. Dzięki przychylności interpretacyjnej ICTY Chorwaci uzyskali potwierdzenie pożądanej przez siebie wersji wydarzeń, związanych z operacja „Oluja” (nie była wymierzona z założenia przeciwko ludności serbskiej). Zgodnie z tym, czyny, łamiące jakiekolwiek prawa, były indywidualnymi „wybrykami” niesubordynowanych żołnierzy, niezgodnymi z planem władz wojskowych Chorwacji. Dalej posuną się jeszcze chorwacki historyk Ante Nazor, który w obszernym wstępie do książki D. Marijana Oluja podważył to, że mordów na ludności serbskiej dokonywali jego ziomkowie. Sugeruje on, że: wielu Serbów poniosło śmierć z powodu licznie popełnianych samobójstw; dużo domów zostało spalonych przez

${ }^{68}$ Presuda. Tužitelj protiv Ante Gotovine, Mladena Markača, Međunarodni sud za krivično gonjenje osoba odgovornih za teška kršenja međunarodnog humanitarno prava počinjena na teritoriju bivše Jugoslavije od 1991., 24 VII 2013, http://www.icty.org/x/cases/gotovina/acjug/ bcs/121116.pdf (dostęp 18 VI 2014). 
samych Serbów, zaś kolumny uchodźców ostrzeliwano, ponieważ ludność cywilna była przemieszana z żołnierzami ${ }^{69}$.

Jednym $\mathrm{z}$ podstawowych problemów $\mathrm{w}$ rozbieżnościach interpretacyjnych, dotyczacych charakteru działań podczas operacji „Oluja”, pozostaje również kwalifikacja dowodów, które mogły zostać uznane lub nie. Najbardziej jaskrawym tego przykładem są zeznania serbskich uchodźców, które - w opinii Serbów - świadczyły o zbrodniach popełnionych na tej ludności podczas przeprowadzania operacji. Natomiast według Chorwatów jest to nieprawda, obliczona na wywołanie antychorwackich nastrojów. Dużą wagę powinny mieć także słowa osób piastujących wysokie stanowiska, które wpływały na kreowanie charakteru wydarzeń. Historyk N. Barić przytoczył słowa byłego chorwackiego ministra obrony Gojko Šušaka, który stwierdził, że celem „Oluji” byto nie tylko wyzwolenie obszarów okupowanych, ale również radykalne zmniejszenie liczby Serbów w Chorwacji. Potwierdzać to mogły też instrukcje prezydenta Tudmana ${ }^{70}$. Był to jeden z przykładów, który i tak nie miał żadnego wpływu na rewizję chorwackiego postrzegania całego wydarzenia.

Innym były raporty helsińskie, które - w opinii Serbów - stanowiły niezbite dowody na łamanie praw człowieka podczas „Oluji”. Tymczasem część z nich, sporządzona w Chorwacji przez ekspertów (opublikowane przez Helsińska

${ }^{69}$ To ostatnie było zgodne $\mathrm{z}$ prawda, czy jednak usprawiedliwiało ostrzeliwanie cywilów? N. Barić, Je li 1995. godine..., s. 460; zob. też: A. Nazor, op. cit., s. 23-24; D. Marijan, op. cit., s. 135; N. Barić, Srpska pobuna..., s. 523; Ž. Juzbašić, op. cit., s. 40. Warto nadmienić, że A. Nazor informacje o samobójstwach uzyskał z doniesień dziennikarki, która z kolei słyszała o tym od jednego z serbskich uchodźców. Sam jednak podważa autentyczność doniesień na temat serbskich ofiar, wskazując na brak jednoznacznej dokumentacji w tej sprawie.

${ }^{70}$ N. Barić, Je li 1995. godine..., s. 458. 
Fundację Praw Człowieka), nie została uwzględniona przez Trybunał w Hadze ${ }^{71}$.

W ostatnich latach przedmiotem dyskusji publicznej stały się także wspomniane powyżej tzw. transkrypty briońskie (zapis rozmowy prezydenta F. Tuđmana $\mathrm{z}$ wysokimi ranga wojskowymi, którzy byli odpowiedzialni za organizację i realizację planu operacji „Oluja”). Znalazły się tam sformułowania analizujące możliwości przebiegu operacji (np. A. Gotovina mówił o możliwości całkowitego zrównania z ziemią Knina w ciagu kilku godzin ${ }^{72}$ ), które zaprzeczały oficjalnemu stanowisku Chorwatów, a także informacjom przekazywanym międzynarodowej opinii publicznej oraz dyplomatom. Strona chorwacka podjęła się jednak interpretacji treści transkryptów, zatrudniając profesora językoznawcę, Ivo Škaricia. Ten przeanalizował dokument, usunął z niego lub zmienił (sic!) niektóre słowa tak, aby - jak stwierdził - stanowiły logiczną całość (pozbawioną wojskowego żargonu). Według Škaricia było to konieczne, aby oddać odpowiednie znaczenie transkryptów, które pozwoliło potwierdzić legitymizację operacji ${ }^{73}$.

Brak dowodów oznaczał niemożność pociagnięcia do odpowiedzialności za popełnione czyny. Jest to kolejna kontrowersja, która dzieli serbską i chorwacką opinię publiczna,

${ }^{71}$ Presuda. Svezak. I od II. Tužitelj protiv Ante Gotovine, Ivana Čermaka, Mladena Markača, Međunarodni sud za krivično gonjenje osoba odgovornih za teška kršenja međunarodnog humanitarnog prava počinjena na teritoriju bivše Jugoslavije od 1991., 15 IV 2011, http://www.icty.org/x/cases/ gotovina/tjug/bcs/110415bcs_judgement_p1.pdf, s. 30 (dostęp 23 V 2014).

${ }^{72}$ „Brijunski transkripti”: Razgovor hrvatskog državnog i vojnog vrha pred zločinačku akciju „Oluja”, „Krajinaforce. Glas krajišnika u egzilu”, http:// www.krajinaforce.com/oluja_brijunski_transkripti.html (dostęp 18 VI 2014).

${ }^{73}$ „Brijunski Transkript” expertiza prof. Ivo Škarić, HAZUD, 18 V 2011, http://www.hazud.ch/2011/05/\%E2\%80\%9Ebrijunski-transkript\%E2\%80\%9E-expertiza-prof-ivo-skaric/ (dostęp $23 \mathrm{~V}$ 2014). 
a także nie pozostaje bez echa w relacjach dyplomatycznych. Raport helsiński z 1996 r. odnotowywał, że wprawdzie bezpośrednio po operacji „Oluja” (w październiku 1995 r.) przedmiotem śledztwa było kilkadziesiąt spraw o popełnienie morderstw, jednak oskarżeni rzadko kiedy byli skazywani ${ }^{74}$.

Z kolei, według danych cytowanych przez N. Baricia, po wojnie do odpowiedzialności pociagnięto 3978 osób, z czego skazano 1492, w tym 26 osób za zabójstwa. Zdaniem Ž. Juzbašicia, zbrodnie przeciwko Serbom nie były efektywnie ścigane, bo Chorwacja nie była tym zainteresowana ${ }^{75}$.

Niezwykle kontrowersyjną kwestia, która wynika w tym przypadku nie tyle z rozbieżności interpretacji chorwackiej i serbskiej, a spekulacji wokół prawdopodobieństwa faktów w ogóle, jest sprawa odpowiedzialności samych Serbów za opuszczenie przez ich rodaków obszaru RSK.

Twierdzi się, że władze RSK wydały decyzję o ewakuacji ludności, co zostało zrealizowane. Faktem jest, że prezydent M. Martić już 4 sierpnia nakazał wyjazd wszystkich osób niezdolnych do stużby wojskowej z obszaru Knina, Benkovaca, Obrovaca, Drniša oraz Gračaca. Zgodnie z planem władz RSK, osoby te miały ewakuować się w kierunku [miejscowości - M. K.-W.] Srb i Donji Lapac ${ }^{76}$. Okolicznością często eksponowana przez chorwackich analityków, by dezawuować rozmiar tragedii nagłaśnianej przez Serbów, jest stwierdzenie, że w momencie rozpoczęcia zbrojnej akcji zdegenerowane, skorumpowane i pogrążone w chaosie władze RSK, podobnie jak wojsko, uciekły. Serbowie podkreślają zaś, iż nieważna była przyczyna ucieczki, a to, że chorwackie wojska dokonywały

${ }^{74}$ Croatia. Impunity for Abuses..., s. 26.

${ }_{75}$ Ž. Juzbašić, op. cit., s. 40; N. Barić, Srpska pobuna..., s. 523; por. Srbi u Hrvatskoj. Jučer, danas $i$ sutra, ur. I. Banac, Zagreb 1998, s. 47, gdzie przytoczona jest liczba 1005 spraw sądowych.

${ }^{76}$ Croatia. Impunity for Abuses..., s. 10, 16. 
zbrodni na uciekających lub pozostałych na miejscu cywilach $^{77}$.

Kolejnym wskazaniem na odpowiedzialność Serbów jest to, że akcja „Oluja” była jedną z odsłon uzgodnionej wojny (dogovoreni rat ${ }^{78}$ ), jaka mieli prowadzić ówcześni prezydenci Chorwacji i Serbii - F. Tuđman i S. Milošević. Potwierdzenie tej hipotezy dzieliłoby winę za przebieg tego wydarzenia zarówno pomiędzy władze chorwackie, jak i serbskie. Co więcej, z moralnego punktu widzenia większa odpowiedzialność za „Oluję” spoczywałaby na serbskim prezydencie. Chorwaci chcieli przecież odzyskać całkowita kontrolę nad obszarami RSK w ramach swego państwa, bez względu na środki, jakie zostały w tym celu użyte. Hipotezę o tzw. uzgodnionej wojnie promował ówczesny burmistrz Knina - D. Kovačević. Strona chorwacka nie potwierdziła takich przypuszczeń, jednak świadczyłyby one o prawdziwości stwierdzeń o planowym usunięciu ludności serbskiej z Chorwacji (a tak zarzuty stawia się władzom RSK, które chciały zrzucić z siebie odpowiedzialność za wojnę $w$ Chorwacji) $^{79}$.

Serbów dodatkowo obciążały wcześniejsze opinie ich ziomków z Chorwacji, że nikt się nimi nie interesuje i nikt o nich nie dba (w znaczeniu politycznym). Chodziło o rozwiazanie problemu chorwackich ziem, zamieszkanych przez ludność serbską, a dotyczyło zarówno Serbii i S. Miloševicia, jak i Republiki Serbskiej w BiH i Radovana Karadžicia. Z kolei belgradzcy Serbowie oskarżali tych z Krajiny (których jakoby zdradzili) o brak zorganizowania solidnej obrony. Faktem jest,

${ }^{77}$ N. Barić, Je li 1995. godine..., s. 452 i nast.; „Oluja” zločin...

${ }^{78}$ N. Barić, Je li 1995. godine..., s. 443; D. Kovačević, op. cit., s. 57.

${ }^{79}$ Co nie byłoby niczym nowym, uwzględniając wspomniane w tekście tzw. humanitarne przesiedlenia, realizowane jednak przy znacząco mniejszej liczbie ludności. 
że zarówno Serbowie z Krajiny, jak i zagraniczni dyplomaci byli przekonani, że w razie ataku Chorwatów Belgrad udzieli militarnego wsparcia Krajinie ${ }^{80}$.

Ponadto, ze strony serbskiej można się spotkać ze zdaniem, że masowa ucieczka Serbów z RSK mogła być środkiem nacisku na Belgrad, zastosowanym przez Zagrzeb, w celu sprowokowania wojsk serbskich do wystapienia przeciwko Chorwatom (S. Milošević miał zapewniać władze RSK, że w razie ataku wojsk chorwackich Serbia nie pozostanie obojętna). Faktem jest, że wielu Serbów uciekało też w obawie przed postawieniem ich przed sądem lub nie wyobrażało sobie ułożenie życia „po sąsiedzku” po wzajemnym wyrządzeniu tylu krzywd ${ }^{81}$.

$$
* * *
$$

Do dzisiaj „Oluja” jest ukazywana w Chorwacji jako dobrowolny exodus Serbów z obszaru Krajiny, zainicjowany paniczną ucieczką zdegenerowanego wojska i władz RSK. Z oburzeniem spotykają się tam próby przedstawienia innej interpretacji tego wydarzenia.

W 2001 r. pokazany został przez telewizję film Božidara Kneževicia Burza nad Krajina (Oluja nad Krajinom), pokazujący wydarzenie oczami serbskich uchodźców i dokumentujacy zbrodnie chorwackie na Serbach. Obraz odebrano jako nieprawdziwy i propagandowy. Generał Janko

${ }^{80}$ Faktem jednak jest, że mimo pomocy militarnej i technicznej, udzielanej w latach 1991-1995, polityka Belgradu i Knina (celem - połaczenie ziem zamieszkanych przez Serbów) była rozbieżna, N. Barić, Je li 1995. godine..., s. 448, 453; D. Marijan, op. cit., s. 139; R. Holbrooke, op. cit., s. 7273; M. Waldenberg, op. cit., s. 149; R. Bilski, op. cit., s. 76; D. Kovačević, op. cit., s. 101; Rat $i$ manjine..., s. 57.

${ }^{81}$ M. Mitrović, op. cit., s. 200; D. Marijan, op. cit., s. 57. 
Bobetko $^{82}$ wystosował list, odczytany $\mathrm{w}$ studio przed emisja filmu, w którym zarzucił, że dokument, pokazujący serbska wersje wydarzeń, miał na celu pomniejszenie doniosłości wojny narodowowyzwoleńczej oraz był wymierzony w bohaterów narodowych ${ }^{83}$.

Można postawić pytanie: Jakie warunki musiałyby zostać spełnione, aby możliwy był proces pojednania między obydwoma narodami? Serbska badaczka, Radmila Nakarada, wymieniła szereg z nich: długotrwały pokój oraz dobrowolność i chęć realizacji pojednania ${ }^{84}$. Uwzględniając okoliczności budowania relacji międzypaństwowych, aktualnie można stwierdzić, że pierwszy warunek jest spełniany. Istnieje prawie dwudziestoletni pokój oraz współpraca między obydwoma państwami i narodami (między Republiką Serbii oraz Republika Chorwacji, jak i na obszarze Chorwacji, gdzie reprezentanci mniejszości serbskiej piastuja mandaty poselskie w Saborze). Chęć realizacji pojednania stanowi już bardziej problematyczny warunek, ponieważ - jak zostało wspomniane - należałoby w pewnym stopniu zaakceptować punkt widzenia drugiej strony.

Kolejne warunki, wymienione przez Nakaradę, to krytyczna autorefleksja o własnym udziale $w$ wywotaniu destrukcyjnego konfliktu oraz empatia wobec cudzych krzywd $i$ ofiar $^{85}$. To powinno mieć miejsce zwłaszcza w okolicznościach, gdy obie strony konfliktu uznają siebie za jego ofiary.

${ }^{82}$ Generał Janko Bobetko oskarżony był przez ICTY o zbrodnie popełnione na Serbach podczas operacji „Medački Džep” w 1993 r. Nigdy nie przyją aktu oskarżenia i nie udał się do Hagi. Zmarł w $2003 \mathrm{r}$.

${ }^{83}$ Oluja nad Krajinom (Factum), part 1/10, https://www.youtube.com/ watch?v=YMi34hNYda4 (dostęp 7 VII 2014).

${ }^{84}$ R. Nakarada, Putevi pomirenja, „Godišnjak” [Beograd] 2011, god. V, br. 5, s. 363 .

${ }^{85}$ Ibidem, s. 364. 
W przypadku operacji „Oluja” tak jest, a jako agresora każdy wskazuje drugą stronę. Dla Serbów RSK była obszarem chronionym przez ONZ, o losie którego miały rozstrzygnąc decyzje międzynarodowe. Operacja wojskowa była więc dla nich agresja. Liczba ofiar serbskich przesłania chorwackie, wypędzone z RSK przed 1995 r. Natomiast Chorwaci negują wielkość zbrodni podczas „Oluji”, pomniejszając rozmiar i charakter ofiar. Ta kluczowa rozbieżność wciąż uniemożliwia znalezienie wspólnej podstawy do rozmów, a wśród Serbów pozostałych w Chorwacji wywołuje rozdźwięki. Część z nich, chcąca szukać współpracy z władzami chorwackimi (przedstawiciele polityczni), bierze również udział np. w uroczystościach wyzwolenia Knina. Można to odczytać jako wyraźny gest pojednania, a także akceptację wydarzeń z sierpnia 1995 r. Spotyka się to z krytyką tej części przedstawicieli mniejszości serbskiej w Chorwacji, która koncentrowała się i koncentruje na krzywdach narodu serbskiego (zarówno w 1995 r., jak i po zakończeniu wojny w Chorwacji). Taka postawa obu stron stoi na przeszkodzie pojednania, podobnie jak kolejna kwestia, a która jest osądzenie zbrodni wojennych. Według Nakarady, aby służyło ono pojednaniu, powinno służyć sprawiedliwości, nie zaś interesom politycznym ${ }^{86}$. Serbowie zarzucaja Trybunałowi w Hadze upolitycznienie, które pozwoliło Chorwacji przystapić do UE - bez osądzenia kluczowych zbrodniarzy. Tych uniewinniono (przykłady Gotoviny i Markača), podczas gdy kwestia współpracy z ICTY hamowała w poważny sposób proces akcesyjny Serbii. Co więcej, fakty potwierdzające taki punkt widzenia, płynęły z samej Hagi (zeznań holenderskiego gen. Cornelisa Nikolaia, służącego w siłach pokojowych ONZ, który stwierdził, że podczas wojny w byłej Jugosławii UNPROFOR

${ }^{86}$ Ibidem, s. 365, 369. 
byt co prawda bezstronny, jednak obwiniano $i$ karano tylko Serbów $w^{87}$.

Serbscy badacze wskazuja wprost na odpowiedzialność polityki Tuđmana. To świadczyłoby, że współczesne państwo chorwackie zostało ukształtowane różnymi, nawet zbrodniczymi, środkami, za co nie rozliczono go. Wprawdzie stanowisko Chorwatów jest niekonsekwentne i niejednorodne, jednak nie zostali oni zmuszeni do weryfikacji lub skonfrontowania się ponownie $\mathrm{z}$ omawianym tu zagadnieniem. Ich wersję wydarzeń potwierdzały czynniki zewnętrzne: państwa i politycy zaangażowani w wojny jugosłowiańskie. Co więcej, odpowiedzialność tę musieliby częściowo wziąć na siebie właśnie dyplomaci, którzy brali udział w kształtowaniu pejzażu polityczno-państwowego współczesnych Bałkanów (z pewnością do tego nie dojdzie). W przypadku „Oluji” odpowiedzialność została zepchnięta na pojedyncze osoby, których nazwiska nigdy nie zostały poznane przez szerszą opinię publiczną.

Istnieje małe prawdopodobieństwo, aby Serbowie i Chorwaci odnaleźli konsensus $\mathrm{w}$ kwestii postrzegania operacji „Oluja”. Trudno też liczyć na wzajemną akceptację stanowiska drugiej strony, bo to by oznaczało konieczność przyjęcia innych punktów widzenia, na co, jak pokazało ostatnie 20 lat, nie ma woli.

${ }^{87}$ „Unprofor u BiH nije bio ni na čijoj strani, a kažnjavali smo samo Srbe”, „Vesti online”, 3 V 2013, http://www.vesti-online.com/Vesti/Ex-YU/310850/Unprofor-u-BiH-nije-bio-ni-na-cijoj-strani-a-kaznjavali-smo-samo-Srbe- (dostęp 7 VII 2014). 